\title{
IDENTIFICATION OF OCCUPATIONAL STRESSORS AMONGST RADIOGRAPHERS
}

\author{
IDENTIFIKACIJA STRESORJEV NA PODROČJU DELA RADIOLOŠKIH INŽENIRJEV
}

\author{
Mihela Jagodič', Valentina Hlebec ${ }^{2}$, Tina Starc ${ }^{3, *}$ \\ ${ }^{1}$ Institute of Oncology Ljubljana, Slovenian National Breast Cancer Screening program - DORA, Zaloška ulica 2, 1000 Ljubljana \\ ${ }^{2}$ University of Ljubljana, Faculty of Social Sciences, Department of Social Informatics, Kardeljeva ploščad 5, 1000 Ljubljana, \\ Slovenia \\ ${ }^{3}$ University of Ljubljana, Faculty of Health Sciences, Department of Medical Imaging and Radiotherapy, Zdravstvena pot 5, \\ 1000 Ljubljana, Slovenia
}

*Corresponding author: tina.starc@zf.uni-lj.si

Received: 25. 2. 2020

Accepted: 17. 4. 2020

https://doi.org/10.47724/MIRTJ.2020.i01.a004

\begin{abstract}
Purpose: The aim of this research is to define stress and correlated factors and identify which stressors are present among radiographers in relation to their workplace.

Methods: A total of 450 radiographers received a questionnaire that covers a variety of workplace stressors, which conditions affect stress, how frequently radiographers notice stress and to what extent they use coping mechanisms. The online survey was available on the website $1 \mathrm{ka}$ and the results were analysed using the IBM SPSS program.
\end{abstract}

Results: A total of 236 radiographers completed the survey (52.4\% response rate). Interpersonal relations and management staff cause the highest level of stress, while the most important stressor is a conflict with a supervisor (3.38). Radiographers who work in a field of radiotherapy perceive the most stress. There is no difference between a healthcare activity in relation to levels of perceived stress. We could not identify any statistically significant differences in perceived stress in relation to gender or age $(p \leq 0.05)$. Radiographers who asses their relationship with co-workers and supervisors as good perceive lower levels of stress. Additionally, the same results are present with radiographers who are satisfied because they work in a multidisciplinary team $(p \leq 0.05)$. Teaching new staff has a positive correlation with occupational stress development. Unnecessary radiological procedures, along with unclear roles, have no effect on the development of stress behaviour ( $p>0.05$ ). However, a conflict between roles has a major association $(p \leq 0.05)$ with stress occurrence. The most frequent methods for reducing symptoms of stress are caring for one's health and physical appearance (3.77). It proved that communication with patients and duty work $(p<0.05)$ represent significant elements of the workload. Most radiographers think that physical conditions in the workplace could be improved.

Discussion and conclusion: The results show that radiographers notice a variety of stressors in their workplace. The most important are related to interpersonal relations. Further research should include analysis of stress within particular fields of radiography that would help to explain occupational stress.

Keywords: occupational stress, stressors, radiographer

\section{IZVLEČEK}

Namen: Namen raziskave je bil ugotoviti, katere stresorje najbolj zaznavajo radiološki inženirji (RI) na svojem delovnem mestu.

Metode dela: Anketni vprašalnik je bil posredovan 450 radiološkim inženirjem. Zanimali so nas stresorji na delovnem mestu, kateri delovni pogoji in obremenitve vplivajo na pojav stresa, kako radiološki inženirji doživljajo fizično stanje na delovnem mestu, v kakšni meri opazijo simptome stresa ter v kolikšni meri se poslužujejo načinov spoprijemanja s stresom. Anketni vprašalnik je bil izveden s pomočjo programa $1 \mathrm{ka}$. Pridobljene rezultate smo analizirali s programom SPSS.

Rezultati: Anketo je rešilo 236 radioloških inženirjev oz. 52,4 \%. Največ stresa zaznavajo RI zaradi medosebnih odnosov ter odnosa vodstvenih delavcev do RI, najpomembnejši stresor je konflikt $z$ nadrejenim $(3,38)$. Stres na delovnem mestu bolj obremenjuje zaposlene na področju radioterapije kot na diagnostičnem. Med različnimi ravnmi zdravstvenih dejavnosti ni razlik $v$ stopnjah zaznanega stresa. Ni statistično značilnih razlik v zaznanem stresu po spolu ter po starosti ( $p \leq 0.05)$. Nižje stopnje stresa zaznavajo tisti, ki so v dobrih odnosih s sodelavci in nadrejenim, ter tisti, ki izražajo zadovoljstvo z delom $v$ multidisciplinarnem timu $(p \leq 0,05)$. Poučevanje novega delovnega kadra je pozitivno povezano s percepcijo delovnega stresa. Spol, starost, nepotrebni dodatni radiološki posegi niso povezani s percepcijo stresa $(p>0,05)$, prav tako ne nejasnost vlog. Ugotovili smo močno povezanost stresa in konflikta vlog $(p \leq 0,05)$. Najpogostejša metoda lajšanja simptomov stresa je lastna skrb za zdravje in videz $(3,77)$, sledijo družabna srečanja $(3,69)$. Pomembni delovni obremenitvi sta komunikacija s pacienti in dežurstva $(p \leq 0,05)$. Večina anketirancev meni, da bi lahko bili fizični pogoji na delovnem mestu boljši.

Razprava in zaključek: Raziskava je pokazala, da RI na svojem delovnem mestu zaznavajo različne stresorje. Najpomembnejši se nanašajo na odnose $v$ samem kolektivu. $V$ prihodnje bi bilo smiselno izvesti raziskave o stresu znotraj posameznih področij radiološke tehnologije, saj bi samo na ta način lahko pridobili najbolj jasno sliko stresa na delovnem mestu.

Ključne besede: stres na delovnem mestu, stresorji, radiološki inženir 


\section{INTRODUCTION}

Today's world is full of challenges, the tempo of life is increasingly faster, and surroundings are more difficult. Consequently, more people at work are coping with stress. In Slovenia, there has been some research done on occupational stress for nurses, but none for radiographers (1). Radiographers are certified healthcare professionals who perform x-ray or magnetic resonance imaging. They are responsible for processing high quality medical images that specialists use to diagnose or track patient's disease or injury (2). They also play an important role in therapeutic treatment (e.g. radiotherapy and nuclear medicine). Rapid technological development demands highly competent and empathic radiographers.

\section{Occupational stress}

Stress is a physiological, psychological and behavioural response to internal and external stimuli (stressors) (3). It is the way our organism responds to changes in the environment (4). Stressors are all factors that cause a stress response and a slight collapse of an individual's inner balance (4) for a short period of time. Given that a stressor does not trigger stress in every person, the interpretation of such an occurrence is thus necessary (5).

Occupational stress can be defined as an imbalance between demands of the workplace and a worker's ability to perform (6). At work, radiographers face many challenges (i.e. radiation exposure, extended working hours, shift work, heavy workload, etc.) that cause stress (2). A common occurrence in the workplace is uncertainty of one's role and therefore role conflict. Inaccurate descriptions of roles and false expectations lead to role ambiguity (7). Role conflict occurs when expectations are not met, and also when an individual performs multiple different roles (8).

Strategies for coping with stress are specific ways of understanding how an individual can handle a stressful situation. We are familiar with problem-oriented and emotionoriented coping mechanisms (9).

\section{AIM}

The aim of the research was to use existing research results and theoretical knowledge to explore the perception of stress in radiographers. Furthermore, we were interested in how the work conditions are related to the perception of stress; whether it was primary, secondary or tertiary health care or the work area of radiographers (i.e. diagnostic or radiotherapy), gender, age, superior's assistance or relationships with colleagues, educating colleagues or students, the association of multidisciplinary team's, the performance of unnecessary radiological procedures, role conflict and role ambiguity, duty hours, communication and staff shortage, physical conditions, equipment and stress-coping methods.

Based on theoretical cues, goals set and research done, we formed twelve hypotheses.

\section{METHODS}

Theoretical bases were built through the review, reading and critical assessment of literature.
The empirical part of research was done using quantitative data collection methods. We obtained data by surveying with the $1 \mathrm{ka}$ web program, which consisted of 29 questions. Five point Likert scales were used to gain insight to the perception of stress- and also, the use of advanced methods for statistical analysis.

The web survey lasted from 10 May 2019 to 5 June 2019. The secretary of the Slovenian Radiographer Association forwarded a survey link to all 413 members. The survey was additionally sent to some radiographers who are not members of the association.

After the research was performed, the data was processed and presented in Excel and SPSS 23.0. Using descriptive statistics, we set basic parameters (i.e. average, standard deviation, minimum and maximum), which we used to determine the stress levels of work situations with different workloads, working conditions and physical conditions. We also studied the influence of interpersonal relationships, social support, role ambiguity, role conflict, stress symptoms and stresscoping methods. Using the Shapiro-Wilk test, we verified the distribution of data and, based on the results, performed parametric and non-parametric tests. Because of different connections and variables, we used a variety of tests, namely a t-test of a single sample, one-way analysis of variance (ANOVA), a t-test of independent samples and Pearson's correlation. Statistically significant changes were $p$-valued (significance level: $p \leq 0.05$ ).

\section{RESULTS AND DISCUSSION}

A total of 236 radiographers correctly filled out the survey, which represents a response rate of $52.4 \%$. Of that total, $72 \%$ (152) were women and $28 \%$ (59) were men. The age distribution of radiographers is equal, while the highest proportion of radiographers $(31.1 \%)$ are between the ages of 20 and 30 years, followed by those between the ages of 30 and 40 years (29.2\%), those between the ages of 40 and 50 years (20.6\%), and those aged from 50 to 60 years (18.6\%). One radiographer was above 60 years old (0.5\%). Most radiographers (176 or $85.4 \%)$ work in the field of diagnostic and interventional radiology, which is expected, as it offers several different fields of employment and requires a large number of employees (Figure 1). A total of $10.7 \%$ of radiographers are employed in radiotherapy, while $3.4 \%$ work in the field of nuclear medicine.

\section{Field of work}

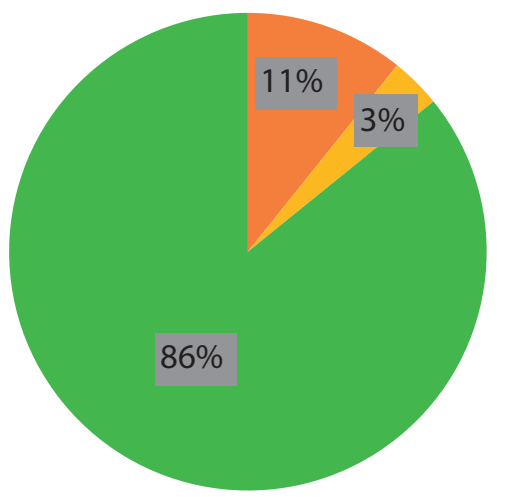

Radiotherapy

- Nuclear medicine

- Diagnostic and interventional radiology

Figure 1: Field of work 
Amongst radiographers who stated that they work in the field of diagnostic and interventional radiology, the majority (77.7\%) work in skeletal and lung diagnostics, followed by radiographers who take images in the intensive care unit (56.6\%), mammography and computer tomography, each employing 63 radiographers, i.e. 36.0\%. Interventional radiology accounts for the smallest percentage, i.e. $13.1 \%$. Most radiographers are employed by university medical centres (32.8\%), followed by general hospital employees $(27.0 \%)$, while the smallest percentage, $10.9 \%$ of respondents, work at the Institute of Oncology.

Certain situations proved to be remarkably stressful, others less so (Table 1). Most stress is caused by a conflict with a superior (average rating of 3.38), followed by inappropriate management style (average rating of 3.36), poor team communication and conflict with colleagues (average rating of 3.28), $p<0.05$. Less stressful situations were work conditions, shift work, work with interns and students, student mentoring, monotonous work and fear of work results. Here the average ratings were below 3 , some even lower than 2 . We determined that four statistically significant situations present high levels of stress for more than half of radiographers ( $\mathrm{N}>118$ ), but we did not prove how many radiographers experience stress in a given situation. We can conclude that the most relevant stressors are linked to management style and interpersonal relationships.

Table 1: Descriptive statistics of stress in work situations

\begin{tabular}{|c|c|c|c|c|}
\hline Work situation & $N$ & average & $\min$ & $\max$ \\
\hline Poor team communication & 218 & 3.28 & 1 & 5 \\
\hline Work conditions & 223 & 2.49 & 1 & 5 \\
\hline Shift work & 187 & 2.17 & 1 & 5 \\
\hline Duty work & 104 & 2.85 & 1 & 5 \\
\hline Conflict with colleagues & 216 & 3.28 & 1 & 5 \\
\hline Conflict with superior & 210 & 3.38 & 1 & 5 \\
\hline Student mentorship & 179 & 1.89 & 1 & 5 \\
\hline Work with interns/students & 190 & 1.84 & 1 & 5 \\
\hline Inappropriate management style & 210 & 3.36 & 1 & 5 \\
\hline Monotonous work & 185 & 2.17 & 1 & 5 \\
\hline Fear of work results & 202 & 2.23 & 1 & 5 \\
\hline Lack of time for required work tasks & 213 & 2.94 & 1 & 5 \\
\hline Extended working hours & 192 & 3.06 & 1 & 5 \\
\hline TOTAL & \multicolumn{2}{|r|}{2.69} & & \\
\hline
\end{tabular}

Using one-way analysis of variance, we discovered that there are statistically significant differences between levels of stress for radiographers employed in different areas in the following work situations: shift work ( $p=0.059$ - marginally significant ), student mentorship ( $p=0.060$ - marginally significant), work with students/interns $(p=0.041)$, extended working hours $(p=0.016)$. Themajority of work situations are most stressful for radiographers employed in radiotherapy. Amongst statistically significant work situations, only extended working hours were more stressful for radiographers employed in nuclear medicine (average rating of 3.75). Using descriptive statistics, we can prove stress in a situation that has no statistically significant differences. Poor team communication caused the most stress for radiographers employed in nuclear medicine (average rating of 4.13 ), as well as conflict with colleagues (average rating of 3.75) and conflict with a superior (average rating of 3.75). Inappropriate management style was the most significant stressor for radiographers in the field of radiotherapy. Work situations are generally most stressful for radiographers employed in radiotherapy and slightly less for radiographers in the field of nuclear medicine. Our findings are in conflict with a study by two researchers that proved that the highest levels of stress are experienced by radiographers in the diagnostic field (10).

Amongst radiographers employed in different medical fields, there are no differences in stress perception in specific work situations ( $p$-value $>0,05$ ). Results are consistent with a study that covered $38 \%$ of radiographers employed in secondary health care facilities, more than $35 \%$ in tertiary educational institutions and $27 \%$ employed in primary health care facilities. It was proven that there were no statistically significant differences in perceived stress amongst respondents (11).

A t-test of independent samples showed that there are no differences between gender in perceived stress; a statistically significant difference $(p \leq 0,05)$ was only visible in fear of work results, which proved to be more stressful for women (average of 2.34). Past gender-based studies have shown that gender does not play a role in levels of perceived stress(12). The researchers Decker and Borg proved in their 1993 study that gender has no statistically significant link to perceived stress (13).

Pearson's correlation shows that age is not a factor in perceived stress. We proved one statistically significant link $(p=0,004)$, i.e. fear of work results, which is greater at a higher age. Other researchers (12) also proved that there is no difference in perceived stress between both age groups $(p=0.07)$.

Pearson's correlation proved that work situations for radiographers are better and less stressful if colleagues and superiors have a good relationship and help each other. The better the relationships are between colleagues, the less stress is perceived due to poor team communication $(r=-0.221)$, work conditions $(r=-0.228)$, duty work $(r=-0.237)$, conflict with colleagues $(r=-0.263)$, and inappropriate management style ( $r=-0.229)$. We also noticed that if colleagues are willing to listen to each other's work-related problems, stress levels are lower due to poor team communication ( $r=-0.203)$, work conditions $(r=-0.180)$, conflict with colleagues $(r=-0.147)$ and inappropriate management style ( $r=-0.159)$. Good interpersonal relationships and social support amongst colleagues have a strong influence on occupational stress. Researchers in their study $(14,15)$ proved that colleagues' and staff's support is one of the most common stress sources. We also discovered how a superior's assistance can influence stress perception in different work situations. If workers receive more support and assistance from their superior, stress perception is lower due to poor team communication ( $r=-0.142)$, work conditions $(r=-0.289)$, duty work $(r=-0.231)$, conflict with a superior $(r=-0.168)$, student mentorship $(r=-0.190)$, work with interns and students $(r=-0.199)$, inappropriate management style $(r=-0.348)$, lack of time for required work tasks $(r=-0.165)$ and extended working hours $(r=-0.312)$. In all cases, there is a negative correlation, but an appropriate management style, superior's support and assistance cause lower stress perception. Receiving positive feedback from superiors ensures a 'feeling of success'.

Radiographers included in the process of training and educating new employees perceive higher amounts of stress 
than those who are not included. The harder it is to train a new employee, the higher amount of stress is perceived due to work conditions $(r=0.135)$, shift work $(r=0.168)$, duty work $(r=0.256)$, conflict with colleagues $(r=0.154)$, conflict with a superior $(r=0.172)$, inappropriate management style $(r=0.213)$, lack of time for required work tasks $(r=0.136)$ and extended working hours $(r=0.218)$. A strong positive correlation was evident in two cases. The higher the perception of effort in teaching new employees, the more stressful is student mentorship $(r=0.654)$ and work with interns and students $(r=0.642)$. Our results were consistent with a study (11) that showed that $35.2 \%$ of those surveyed who work in teaching-research hospitals are under a great deal of stress.

Radiographers who are satisfied with team work and professional cooperation perceive less stress than those who are not of the same opinion. The more valued radiographers are by radiologists and medical specialists, the less stress is perceived in work conditions $(r=-0.212)$, shift work $(r=-0.165)$, duty work ( $r=-0.235)$, conflict with colleagues $(r=-0.204)$, conflict with a superior $(r=-0.255)$, mentorship $(r=-0.187)$, work with interns and students $(r=-0.191)$, inappropriate management style $(r=-0.308)$, fear of work results $(r=-0.379)$, lack of time for required work tasks $(r=-0.238)$ and extended working hours ( $r=-0.218)$.

Radiographers who are of the opinion that they perform unnecessary additional procedures are neither more or less stressed than those who do not share the same standpoint. Pearson's correlation did not show any statistically significant link ( $p>0.05)$.

Our aim was to determine whether radiographers who are aware of their competence and responsibilities perceive lower levels of stress. We started analysing assertions related to role ambiguity. Radiographers who feel more responsibility perceive higher levels of stress when in conflict with a superior $(r=0.141)$. Radiographers who know what is expected of them perceive lower levels of stress when working with interns/students ( $r=-$ $0.162)$, inappropriate management style $(r=-0.182)$ and fear of work results $(r=-0.154)$. We proved that role ambiguity does not significantly affect occupational stress levels, but role conflict has a major impact on stress perception in different work situations, as nearly all assertions and situations expressed statistically significant codependency. One of the assertions about role conflict illustrated in a work situation is as follows: the more radiographers think that they work in a manner that should be different, the higher stress perception is in team communication $(r=0.166)$, work conditions $(r=0.305)$, shift work $(r=0.217)$, duty work $(r=0.282)$, conflict with a superior $(r=0.139)$, working with interns/students $(r=0.166)$, inappropriate management style $(r=0.206)$, lack of time for required work tasks (0.150) and extended working hours ( $r=0.152)$. In a study done by two researchers (10), role conflict $(r=0.53)$ also caused stronger stress perception than role ambiguity ( $r=-0.31)$.

Radiographers use different techniques for reducing stress; mostly they take care of their health and appearance by consuming healthy food (average rating of 3.77), while some seek relaxation in sport (average rating of 3.53) but it is not the most common stress coping technique used.

Wealso studied whether communication with patients, workduty and staff deficiency represent the most significant workloads. Work duty and communication with patients have shown statistically significant links related to stress perception in work situations $(p<0.05)$. Those surveyed ascribe great importance to attitude towards a patient, which presents no stress to them. Stress perception rises due to poor communication when patients are uncooperative, radiographers lack time to explain directions and properly treat a patient or show empathy for the individual. Polworth (1982) made the same point in his study, which explains that work and communicating with patients are not stress factors for radiographers (17).

Using descriptive statistics, we determined that radiographers find duty work most stressful (average rating of 3.35), and that they are burdened with too much responsibility while on duty (average rating of 3.18). Pearson's correlation also showed significant links between duty work and stress levels of work situations, such as: the more stressful radiographers find duty work, the higher stress perception is due to work conditions ( $r=0.361)$, conflict with colleagues $(r=0.272)$, lack of time for required work tasks $(r=0.311)$, extended working hours $(r=0.370)$. The more demanding duty work is for radiographers, the higher stress perception is due to poor team communication ( $r=0.295)$, work conditions $(r=0.436)$, inappropriate management style $(r=0.301)$, fear of work results $(r=0.268)$, lack of time for required work tasks $(r=0.386)$, and extended working hours $(r=0.367)$. To sum up, duty work is highly stressful for radiographers.

Lack of staff did not show statistically significant links in linear correlation. Using descriptive statistics, we did, however, discover that $64.6 \%$ of radiographers think that employability is too low, while $96.6 \%$ of radiographers are of the opinion that a larger number of employees would reduce stress levels. Most radiographers are satisfied with room lighting (average rating of 3.40), although they are not as satisfied with room temperature and air flow (average rating of 2.29). They neither agree or disagree with the assertion that work premises and equipment in the department fail to meet staff needs (average rating of 3.05). The same applies to the assertion that the quality of image diagnostics is good (average rating of 3.32). Radiographers agree that equipment is well maintained (average rating of 3.64). Most radiographers think that there are not enough diagnostic devices in an institution according to the number of different procedures performed (average rating of 3.51). A study performed by Polworth (1982) exposed multiple physical stressors, including insufficient workspace with bad airflow and lighting (17).

\section{CONCLUSION}

Our research was the first research on occupational stress for radiographers in Slovenia. We determined that radiographers are subjected to occupational stress. Most problems are caused by interpersonal relationships and management. Because it was the first research of stressors, our goal was to study stressors amongst all radiographers. In the future, we suggest that every field of radiography be studied individually (nuclear medicine, radiotherapy, diagnostic and interventional radiology) or within the specific departments of certain institutions. Only in this way can we get a clear picture of the most common stress sources, so that management can take the appropriate action. We suggest more surveys about satisfaction, staff burnout and stress perception within radiological departments, as well as psychological lectures about stress and interpersonal relationships. 


\section{References}

1. Franci D (2015). Analiza vpliva stresa in izgorevanja pri medicinskih sestrah $\mathrm{v}$ enotah intenzivne terapije. Magistrsko delo. Maribor: Fakulteta za zdravstvene vede. Dostopno na: https://dk.um.si//zpisGradiva.php?id=47386

2. Rajan D, Phil M. Stress: among Radiographers. SCMS Journal of Indian Management. 2014; 11(2): 71 - 86.

3. Dernovšek $M Z$, Gorenc $M$, Jeriček $H$. Ko te strese stres. Ljubljana: Inštitut za varovanje zdravja Republike Slovenije, 2006.

4. Newhouse P. Življenje brez stresa. Ljubljana: Tomark, 2000.

5. Prah S. Predihajmo stres: Priročnik za sproščanje. Novo mesto: Psihoterapevtsko društvo Izbira, 2015.

6. Bilban M. Kako prepoznati stres $\mathrm{v}$ delovnem okolju. Preprečimo, da nas strese stres na delovnem mestu zbornik predavanj [internet]. 2009 [cited 2019 Feb 20]; 21 - 35. Available from: https://www.zbornica-zveza.si/sites/ default/files/publication_attachments/preprecimo_da_ nas_strese_stres_na_delovnem_mestu_0.pdf

7. Ugwu AC, Ahamefule KN, Nwobi IC. Radiographer's experiences of stress and methods of coping: a content analytic phenomenological study. The radiographer. 2008; 55 (1): 25 - 29.

8. Kendall E, Murphy P, O'Neill V, Bursnall S. Occupational stress: factors that contribute to its occurrence and effective management [internet]. 2000 [cited 2019 Jan 23]; 1 - 158. Available from: http://www. mentalhealthpromotion.net/resources/occupationalstress-fractors-that-contribute-to-its-occurrence-andeffective-management.pdf
9. Meško M. Stres na delovnem mestu: visokošolski učbenik z recenzijo. Ljubljana: Zavod za varnostne strategije pri Univerzi v Ljubljani, 2011.

10. Rutter DR, Lovegrove MJ. Occupational stress and its predictors in radiographers. Radiography. 2008; 14: 138 $-143$.

11. Ashong GGNA, Rogers $H$, Botwe BO, Anim-Sampong S. Effects of occupational stress and coping mechanisms adopted by radiographers in Ghana. Radiography. 2016; 22: $112-117$.

12. Ugwu AC, Erondu OF, Umeano UB. Psychosocial stress and its predictors among radiographers in South-eastern Nigeria. The South African radiographer. 2011; 49 (2): 11 15.

13. Gamalendira S, Rosario S, Anutheepa A in Harshani PAS. Assessment of occupational stress level among the diagnostic radiographers of Kandy District in Sri Lanka. International Journal of Perceptions in Public Health. 2017; 1(3): 205 - 209.

14. Eslick GD, Raj VV. Occupational stress amongst Australian radiographers: prevalence, risk factors, job satisfaction and impact. The Radiographer. 2000; 47 (3): 129-33.

15. Eslick GD, Raj VV. Occupational stress amongst radiographers: does working in private or public practice make a difference? Radiography. 2002; 8: 47-53.

16. Casselden PA. The personality of radiographers: empathy dimensions and the management of occupational problems and stress. Radiography. 1988; 54: $77-82$.

17. Polworth E. Occupational stress and the radiographer. Radiologic technology. 1982; 51: 91 - 103. 